\title{
Миляуша Закирова
}

\section{Robert Argenbright. Moscow under Construction: City Building, Place-Based Pro- test, and Civil Society. Lanham, MD: Lexington Books, 2016. 218 pp. ISBN 978-1- 4985-2203-8.}

\begin{abstract}
Миляуша Закирова - исследователь центра Йордана по изучению России при Нью-Йоркском университете. Адрес для переписки: Jordan Center for the Advanced Study of Russia, New York University, 19 University Place, New York, NY 10003, USA.mz78@nyu.edu.
\end{abstract}

В 2007 году объединенной редакцией изданий мэра и правительства Москвы был опубликован двуязычный фотоальбом «Москва строится / Moscow under Construction», со страниц которого мэр столицы Юрий Лужков с гордостью предлагал ознакомиться с преображениями города на рубеже веков. Неизвестно, намеренно ли, но спустя почти десять лет, в 2016 году, американский географ Роберт Аргенбрайт вступил с бывшим градоначальником в диалог, критически осмыслив эти преображения в своей книге со сходным названием.

Автор ставит своей целью изучить рост местного (place-based) сопротивления практикам преобразования Москвы, в результате которого происходит изменение в городском режиме управления и расширение «права на город» жителей, получающих все больше возможностей участвовать в изменении привычных для них мест и города в целом. Аргенбрайт хорошо знает Москву, с которой его связывают личные и продолжительные отношения, а также демонстрирует подробное знакомство с российскими исследованиями локального протеста.

Ссылаясь на множество исторических фактов, автор концентрирует основное внимание на обширном временном отрезке с начала 1990-х годов до начала 2016 года. Несмотря на то, что этот период захватывает деятельность трех московских градоначальников, основным антагонистом горожан в книге выступает Юрий Лужков, стоявший во главе города 18 лет (1992-2010), и по масштабам градостроительной деятельности, развернутой в столице, сравнимый только с Иосифом Сталиным (с. 85). Рассматривая деятельность Сергея Собянина, автор только намекает на его решительность, но действия нового мэра по преобразованию города (например, снос торговых палаток) в эту работу не попали.

Работа состоит из семи расположенных не в хронологическом порядке глав, заключения и примечания. Аргенбрайт начинает и завершает книгу разъяснением своей теоретической модели. Автор называет «производство места» основной категорией своего исследования. «Место» определяется им не как вещь, а как «своеобразно составленное и расположенное сочетание процессов» (с. 12), то есть место динамично, оно должно производиться, поддерживаться и переделываться. Переосмысляя теорию Бруно Латура, автор лишает вещи роли акторов, однако они, обладая «властью присутствия» (с. 163), все же влияют на процесс производства мест. Этот подход, к сожалению, нашел слабое выражение в анализе эмпири- 
ческого материала, и места остались статичными, как будто содержание аргументов протестующих горожан и их понимание того, что же они защищают, раз сформулированное, остается неизменным и не корректируется под воздействием множества факторов. Автор не различает места, для него и разрушение исторических построек в Малом Козихинском переулке, и сопротивление выселению жильцов Южного Бутова, и строительство храма Христа Спасителя оказываются явлениями одного порядка.

Вторая глава посвящается осмыслению результатов постсоветских трансформаций. Так, категория «гражданское общество», обозначенная в заглавии книги, рассматривается автором применительно к специфике российского контекста. Изменения, переживаемые постсоветской Россией, привели к неожиданным для многих на Западе результатам, и поэтому здесь имеет смысл не искать гражданское общество в западном понимании, а рассматривать его эффекты. Ориентированные на результат инициативные группы, выступающие против того или иного градостроительного решения властей, в России приобретают особую значимость, так как их влияние на реформирование городского управления и есть один из эффектов гражданского общества. Поднимая вопросы справедливости и расширяя спектр союзников, деятельность этих групп способствует включению россиян в политический процесс.

Третья глава полностью посвящена детальному описанию резонансного случая сопротивления строительству в Малом Козихинском переулке, на примере которого автор продемонстрировал противоречия и динамику взаимоотношений властей города и активистов из числа местных жителей и городских движений.

Обращаясь к истокам проблемы, в четвертой главе автор описывает «машину» Лужкова, в противостоянии которой возникают локальные инициативные группы. Это обобщение конкретизируется примерами, представленными в пятой главе. После распада Советского Союза Москва при непосредственном участии мэра открыла множество возможностей и стала привлекательной во многих отношениях. Однако несмотря на наплыв частного капитала, режим управления столицей нельзя было назвать неолиберальным - городское правительство являлось самым крупным землевладельцем и обладало полным контролем над экономикой города, всячески препятствуя приватизации земли и городских объектов. Подобная сверхконцентрация власти, воплощенная в одной фигуре, по мнению автора, способствовала мобилизации недовольных горожан - они легко могли определить виновника своих проблем. Большинство решений городской власти осуществлялись негласно, что также усугубляло конфликт с горожанами, которые оказывались во власти слухов и домыслов. Отсутствие действующего генерального плана развития города только усиливало неопределенность участи значимых для горожан мест, а также открывало возможности для строительных маневров.

Аргенбрайт выделяет две линии аргументации Лужковым своих начинаний. Во-первых, это восстановление исторического наследия, разрушенного «варварами» в советские годы, которое воплотилось, например, в создании «новых старых национальных сакральных мест» (с. 48). Во-вторых, это стремление к удобству горожан, что часто отождествлялось с удобством автомобилистов. Многие проек- 
ты, призванные повысить уважение к градоначальнику, обнажили проблемы его руководства, среди них автор выделяет авторитаризм в выборе проектов, в которых часто прослеживался личный вкус мэра; непрозрачность процесса строительства, которое по итогам нередко критиковалось за излишнюю дороговизну и низкое качество работ; вольное отношение к историко-культурным памятникам, выраженное, например, в их замене «муляжами» (с. 64). Подобная градостроительная политика, по мнению критиков, вела к потере городом аутентичности и упрощению городского ландшафта - город постепенно превращался в «тематический парк» (с. 51). Юрий Лужков как создатель эрзац-симулякров, считает Аргенбрайт, предстал образцовым постмодернистом.

Шестая глава посвящена правлению Собянина, которое автор рассматривает на примере отношения нового мэра к семи наиболее конфликтным объектам города, доставшимся ему в наследство от предыдущего руководства. Новое правительство автор считает более профессиональным и открытым для диалога с горожанами, которые сейчас могут участвовать в решении городских вопросов посредством электронных ресурсов, а это при всей критике является положительным изменением. Принцип негласности Лужкова был нарушен также в результате включения представителей городских общественных организаций в консультативные органы мэрии. Трансформировались и отношения собственности: помимо активного привлечения частных средств в реконструкцию исторических объектов, московское правительство изменило правила их аренды и разрешило их продажу.

Завершая книгу, автор отходит от темы сохранения исторических памятников и посвящает седьмую главу возникновению культуры протеста на примере выступлений москвичей против посягательств на их дома.

Сожаление вызвало поверхностное рассмотрение автором социально-экономических характеристик протестующих и изменений статуса горожан в результате постсоветских реформ. Читателю покажется, что единственным собственником в городе является его администрация, однако социально-экономическая картина российского города сложнее. Кроме того, формальное «закрепление» за определенным местом в виде регистрации по месту жительства или права собственности здесь во многом определяет возможности горожан и характер сопротивления изменениям их жилой среды.

Читатель книги узнает о протестующих горожанах недостаточно. Так, например, подробно описывая случай застройки Малого Козихинского переулка в центре столицы, автор использует термин «джентрификация», но не раскрывает его. Районы столицы различаются сейчас, но различались и в советское время (Бессонова 2011; Трущенко 1995; Morton 1987), когда центр города в большей степени был населен представителями элиты, не полностью растерявшей свои возможности и в настоящее время. Ведь не просто так «лицом» этого протеста стала народная артистка Татьяна Догилева.

Проблематичным представляется и смешение сил, противостоящих решениям мэрии. Автор подробно описывает развитие и деятельность общегородских движений, Всероссийского общества охраны памятников истории и культуры (В00ПиК) и «Архнадзора», их участие в мониторинге проблемных объектов на город- 
ской карте, в просвещенческих проектах и работе со СМИ. Также он упоминает и городские политические силы, аргументы которых выходят далеко за пределы защиты отдельных городских объектов. Однако он не рассматривает роль этих объединений «среднего уровня» в изменении аргументации недовольных горожан и их интеграционную деятельность.

Автор наглядно демонстрирует включение горожан в процесс управления столицей через рост их участия в выявлении и мониторинге исторически значимых объектов городского ландшафта. Это ценное наблюдение делает работу привлекательной для широкого спектра специалистов, но и непосвященный читатель найдет эту книгу увлекательной.

\section{СПИСОК ЛИТЕРАТУРЫ}

Бессонова, Ольга. 2011. Жилищный раздаток и модернизация России. М.: РОССПЭН.

Трущенко, Ольга. 1995. Престиж центра: городская социальная сегрегация в Москве. М.: SосіоLogos.

Morton, Henry. 1987. "Housing Quality and Housing Classes in the Soviet Union." Pp. 95-116 in Quality of Life in the Soviet Union, edited by Horst Herlemann. Boulder, C0: Westview Press. 